\title{
Levels of protein and fat produced by black soldier fly (hementia illucens) larvae in the bioconversion of organic waste
}

\author{
Heni Aristi ${ }^{1 *}$, Era H. Mudji ${ }^{2}$, Koesnoto Soepranianondo ${ }^{3}$, Nenny Haridjani ${ }^{4}$, and Zelvy Aprilia ${ }^{5}$ \\ ${ }^{1}$ Master Program of Veterinary Agribusiness, Faculty of Veterinary Medicine, Airlangga University Kampus C, Margomulyo, \\ Surabaya, East Java, 60115, Indonesia \\ ${ }^{2}$ Doctoral Program of Veterinary Science, Faculty of Veterinary Medicine, Airlangga University Kampus C, Margomulyo, \\ Surabaya, East Java, 60115, Indonesia \\ ${ }^{3}$ Department of Animal Husbandry, Faculty of Veterinary Medicine, Airlangga University Kampus C, Margomulyo, Surabaya, East \\ Java, 60115, Indonesia \\ ${ }^{4}$ Department of Veterinary Public Health, Faculty of Veterinary Medicine, Airlangga University Kampus C, Margomulyo, Surabaya, \\ East Java, 60115, Indonesia \\ ${ }^{5}$ Faculty of Veterinary Medicine, Wijaya Kusuma University, Jl. Dukuh Kupang XXV Dukuh Kupang, Dukuh Pakis, East Java, \\ 60225, Indonesia
}

\begin{abstract}
Larvae are the longest phase in the life cycle of Black Soldier Fly (BSF), making them classified as bioconversion agents. This study aims to determine the protein and fat levels of Black Soldier Fly larvae that are fed with different organic wastes (cabbage, tomatoes, carrots and a mixture of all three). This study is an experimental study using a completely randomized design (CRD) with four treatments and six replications. The four treatments are P1 (6 kg mixed cabbage, tomato, and carrot waste), P2 (6 kg cabbage waste), P3 (6 kg tomato waste), and P4 (6 kg carrot waste). The research was conducted for 12 days using 5 day-old larvae. Collected data were analyzed using a one-way Variance of Analysis (ANOVA) method. The results showed a significant difference $(\mathrm{P}<0.01)$ between mixed media, cabbage media, tomato media, and carrot media with the highest average protein content found in tomato media 11,4267 . While the fat level test did not show a significant difference $(\mathrm{P}>0.05)$ with the highest average fat content found in carrot media by 0.9533. The nutrition of Black Soldier Fly larvae is greatly influenced by the breeding media. Different nutrients will cause different nutrient content in the larvae.
\end{abstract}

Keywords: black soldier fly, fat level, protein level, organic waste.

\section{Introduction}

The increase in the human population in the world is followed by more and more garbage generated, including organic waste with a variety of types. Until now, organic waste has not been used optimally. One way to process organic waste into high-value and useful products is by recycling or also called bioconversion. Bioconversion is carried out by utilizing the Black Soldier Fly (BSF) and microorganisms as decomposers. Utilization of BSF hermentia illucens L. (Diptera: Stratiomyidae) is one of the innovative strategies and has enormous potential as an organic waste treatment method [2] to overcome the problems of improper organic waste management can cause various problems such as the source of disease, the cause of unpleasant odors, damage, and pollution to water, soil, and air which ultimately causes global warming [7].

\section{Materials and methods}

This study used twenty-four test samples consisting of four treatments and six repetitions. Each treatment is called P1, P2, P3, and P4. The treatments included: $\mathrm{P} 1=$ Six craps of a mixture of cabbage, carrot and tomato waste weighing $6 \mathrm{~kg}$ each.

$\mathrm{P} 2=$ Six craps of cabbage waste weighing $6 \mathrm{~kg}$ each. P3 = Six craps of tomato waste weighing $6 \mathrm{~kg}$ each. P4 = Six craps of carrot waste weighing $6 \mathrm{~kg}$ each.

\subsection{Reseach Procedure}

1. Five-day-old Hermetia illucens larvae as much as 6.90 grams were sown on plastic scrap containing cabbage waste, tomato waste, carrot waste, and mixed waste media.

\footnotetext{
* Corresponding author: heni_aristi@yahoo.com
} 
2. The growing containers were 24 pieces, each of which was filled with $6 \mathrm{~kg}$ of organic waste as a growing medium. Control was carried out every day in the morning at 10:00 WIB for 12 days. is is

3. 17-day-old larvae in the media were then harvested using water and a $5 \mathrm{~mm}$ sieve. is. íp.]

4. The harvested larvae were tested in the laboratory to determine their protein and fat levels.

\section{Results and Discussion}

Data obtained from this study are presented in Tabel 1 and Tabel 2.

Table 1. BSF Larvae Protein Level Test Result

\begin{tabular}{ll}
\hline Treatment & Average \pm SD \\
\hline Mixed Waste & $10.08 \pm 0.37^{\mathrm{a}}$ \\
Cabbage & $9.61 \pm 0.31^{\mathrm{a}}$ \\
Tomato & $11.42 \pm 0.5^{\mathrm{b}}$ \\
Carrot & $11.25 \pm 0.49^{\mathrm{b}}$
\end{tabular}

Note: Different superscript shows a significant differences $(\mathrm{p}<0.05)$

Table 2. BSF Larvae Fat Level test Result

\begin{tabular}{ll}
\hline Treatment & Average \pm SD \\
\hline Mixed Waste & $0.66 \pm 0.27$ \\
Cabbage & $0.55 \pm 0.29$ \\
Tomato & $0.52 \pm 0.12$ \\
Carrot & $0.95 \pm 0.54$ \\
\hline
\end{tabular}

Differences in nutrition in the feed will cause various nutritional content of larvae. The nutrition of Hermetia illucens larvae is strongly influenced by the media in which they breed. If the media is rich in protein, larvae will contain high protein, and the same thing happens with media with high levels of fat or fiber [12].

In this research, it is known that tomato waste has a higher protein content compared to other types of waste, which is 11.4267 followed by carrot waste, a mixture of various rubbish and cabbage waste. This is caused by tomatoes containing polyphenols, carotenoids, and vitamin $\mathrm{C}$ which function as antioxidants. The polyphenols in tomatoes consist mostly of flavonoids, while the lycopene pigment is the dominant type of carotene. The contents do not dissolve easily or are lost because they are tightly bound in the fiber [14].

While the highest fat content in this study contained in carrot waste amounted to 0.9533 . That is because carrots are rich in $\beta$-carotene, protein, carbohydrates, fiber, fat, vitamins $\mathrm{A}, \mathrm{C}, \mathrm{E}$ and calcium and phosphorus. Vitamin $\mathrm{A}$ has a function in the proliferation of intestinal and muscle cells which causes an increase in the number of cells in the intestine to absorb food. Vitamins $\mathrm{C}$ and $\mathrm{E}$ function as natural antioxidants that protect cells and tissues from damage caused by free radicals [15]. BSF larvae in carrot waste media are a good source of fat in livestock. In addition to reducing production costs, it can also overcome the problem of environmental pollution due to the accumulation of food scraps that lead to the emergence of various diseases [9].

\section{Conclusion}

The provision of organic waste affects the protein content and fat of larvae of Black Soldier Fly with the highest average protein content found in tomato media of 11.4267 and the highest average fat content found in carrot media of 0.9533 . This can be used to reduce the cost of food for livestock and to overcome various problems caused by organic waste, especially in tomato and carrot waste.

\section{References}

1. Diener S, Zurbrügg C, Gutiérrez FR, et al.: Black soldier fly larvae for organic waste treatment-prospects and constraints. In: Alamgir M, Bari QH, Rafizul IM, Islam SMT, Sarkar G, Howlader MK, editors. Proceedings of the WasteSafe 2011-2nd International Conference on Solid Waste Management in Developing Countries; 2011 Feb 1315; Khulna, Bangladesh. Khulna (BD): ResearchGate. 2011; 52-59.

2. Gabler F : Using a black soldier fly for waste recycling and effective Salmonella spp. reduction [theses]. Swedish (SE): University of Agricultural Sciences. 2014.

3. Gobbi P, Martínez-Sánchez A, Rojo S: The effects of larval diet on adult life-history traits of the black soldier fly, Hermetia illucens (Diptera: Stratiomyidae). Eur J Entomol. 2013 ; 110(3):461- 468.

4. Handrian RS, Meiriani, Haryati : Increased Vitamin C Level of Tomato Fruit (Lycopersicum Esculentum Mill.) in Lowland through Ga3 Hormone administration. Jurnal Online Agroekoteknologi. 2013; 2 (1): 333-339.

5. Hayes D, Laudan R: Food and Nutrition / Editorial Advisers, Dayle Hayes, Rachel Laudan. Marshall Cavendish. New York. 2008.

6. Muzaki MDR, Mahfudz LD, Muryani : Effect of Carrot Waste Flour (Daucus Carrota L) Usage in Rations through the Performance of Broiler Chickens. Jurnal Ilmu Ternak. 2017; 17 (1).

7. Monita L : Bioconversion of Organic Waste Using Black Soldier Fly (Hermetia Illucens) Larvae and Em4 in order to Support Sustainable Waste Management. Thesis. Institut Pertanian Bogor. Bogor. 2017.

8. Fahmi MR: Optimization of Bioconversion Process Using Mini-larvae of Hermetia illucens to Meet Fish Feed Needs. Pros Sem Nas Masy Biodiv Indon. Depok. 2015; 1(1): 139-144.

9. Fahmi MR, Hem S, Subamia IW. : Maggot Potential to Increase Growth and Health Status of Fish. Jurnal Riset Akuakultur. 2009; 4(2): 221-232.

10. Muzaki MDR, Mahfudz LD, Muryani, R : Effect of Carrot Waste Flour (Daucus Carrota L) Usage in Rations through the Performance of Broiler Chickens. Jurnal Ilmu Ternak. 2017; 17 (1). 
11. Newton GL, Sheppard DC, Watson DW, et al. : The black soldier fly, hermetia illucens, as amanure management/resource recovery tool. 2005 .

12. Tschirner M, Simon A : Influence of different growing substrates and processing on the nutrient composition of black soldier fly larvae destined for animal feed. $J$. of Insects as Food and Feed. 2015; 1: 249-259.

13. Rachmawati, Buchori D, Hidayat $\mathrm{P}$, et al. : Development and Nutritional Content of Hermetia Illucens (Linnaeus) Larvae (Diptera: Stratiomyidae) in Oil Palm Cake. J Entomol Indon. 2010; 7(1): 28-41.
14. Sunarmani, Tanti K. : Parameters of Lycopene in Standardizing Tomato Fruit Concentrates. A Research of Center for Agricultural Postharvest Research and Development. 2008.

15. Wardhany BAK, Cholissodin I, Santoso E : Determination of Animal Feed Composition to Meet the Nutrition Needs of Laying Hen with Minimum Costs Using Particle Swarm Optimization (PSO). Jurnal Pengembangan Teknologi Informasi dan Ilmu Komputer. 2017;1(12): 1642-1651. 